\title{
INDUKSI KETAHANAN TANAMAN JAHE TERHADAP PENYAKIT LAYU Ralstonia solanacearum RAS 4 MENGGUNAKAN FUNGI MIKORIZA ARBUSKULAR (FMA) INDIGENUS
}

\author{
Netty Suharti ${ }^{1}$, Trimurti Habazar ${ }^{3}$, Nasril Nasir ${ }^{2}$, Dachryanus $^{1} \&$ Jamsari $^{3}$ \\ ${ }^{1}$ Fakultas Farmasi Universitas Andalas \\ ${ }^{2}$ Jurusan Biologi Fakultas Matematika dan Ilmu Pengetahuan Alam Universitas Andalas \\ ${ }^{3}$ Fakultas Pertanian Universitas Andalas \\ e-mail:nettysuharti@yahoo.com
}

\begin{abstract}
Induce resistance of ginger to Wilt disease caused by Ralstonia solanacearum race 4 with indigenous arbuscular mycorrhyzae fungi (AMF). Bacterial wilt disease caused by Ralstonia solanacearum race 4 is a yield-limiting disease of ginger. A study to investigate the ability of indigenous Arbuscular Mycorrhizae Fungi (AMF) to reduce bacteria wilt disease has been done. This research was designed by using Randomized Block Design (RBD) at greenhouse experiments, using eight AMF isolates with six replication. As supporting data, population $R$. solanacearum race 4 after treatments was assesed. The results showed that aplication of indigenous AMF to ginger rhizome as seed treatment dicreased disease incidence, support ginger growth and production such as the seedling formation $150 \%$, plant height $98.6 \%$, the number of leaf $115,7 \%$. As the result yield of ginger rhizome increased by $400 \%$ and phyloplan $598,3 \%$, respectively, compared to the control.
\end{abstract}

Key words: Arbuscular Mycorrhizae Fungi, bacterial wilt disease, ginger, Ralstonia solanacearum race 4

\section{ABSTRAK}

Induksi ketahanan tanaman jahe terhadap penyakit layu Ralstonia solanacearum ras 4 menggunakan fungi mikoriza arbuskular (FMA) indigenus. Penyakit layu bakteri yang disebabkan oleh Ralstonia solanacearum ras 4 merupakan faktor penghambat produtivitas anaman jahe. Serangkaian peneltian yang bertujuan untuk mengetahui kemampuan Fungi Mikoriza Arbuskula (FMA) indigenus dalam mengendalikan penyakit layu bakteri pada tanaman jahe telah dilakukan pada percobaan pot di Rumah Kaca, menggunakan Rancangan Acak Kelompok (RAK), dengan perlakuan 8 isolat FMA dan 6 ulangan. Populasi $R$. solanacearum ras 4 pada jaringan akar tanaman jahe dihitung setelah dilakukan inokulasi. Hasil penelitian menunjukkan bahwa aplikasi FMA indigenus pada rimpang jahe dapat menurunkan kejadian penyakit dan meningkatkan pertumbuhan dan produktivitas tanaman jahe, meliputi jumlah anakan $150 \%$, tinggi tanaman $98,6 \%$, jumlah daun $115,7 \%$, hasil rimpang 400\%, dan bagian atas tanaman (tajuk) 598,3\% dibanding tanaman kontrol.

Key words: Arbuscular Mycorrhizae Fungi, bacterial wilt disease, ginger, Ralstonia solanacearum race 4

\section{PENDAHULUAN}

Jahe (Zingiber officinale Rosc.) merupakan salah satu tanaman rempah dan obat yang sudah sejak lama dikenal oleh masyarakat karena mempunyai banyak kegunaan. Tanaman jahe termasuk salah satu komoditi unggulan dan dipertimbangkan dapat turut serta dalam usaha menggalakkan komoditi non migas, sehingga mendapat perhatian untuk dikem bangkan di Indonesia (Wattimena, 2004; Suratman et al., 1987).

Secara nasional produksi jahe masih rendah dan terjadi penurunan luas panen dan produktivitas. Pada tahun 1999 sampai 2003 luas panen jahe berkisar antara 23.700-25.400 ha dengan produksi 6,26 ton/ha menjadi 4,41 ton/ha (Badan Pusat Statistik Indonesia, 2003). Secara normal produksi jahe dapat mencapai 20-30 ton/ ha (Suratman et al., 2000; Tumbuh, 1991; Trubus, 1990; Annonim, 1989).

Salah satu penyebab penurunan luas panen dan produktivitas jahe adalah gangguan penyakit layu bakteri yang disebabkan oleh Ralstonia solanacearum ras 4. Patogen ini sulit dikendalikan, karena dapat bertahan paling singkat satu tahun dalam tanah tanpa kehilangan virulensinya, serta menyerang tanaman pada berbagai fase pertumbuhan. Di Hawaii, patogen ini dapat menyebabkan kehilangan hasil pada tanaman jahe lebih dari 45\% (Alvarez et al., 2004; Stansbury et al., 2001). Penyakit layu bakteri pada tanaman jahe telah memusnahkan pertanaman jahe di sebagian besar wilayah Asia seperti India, Philipina, Thailand dan Indonesia (Elphinstone, 2004). Dari Kabupaten Solok sebagai salah satu sentra produksi jahe Sumatera Barat 
diinformasikan bahwa, semenjak tahun 2000 patogen ini telah memusnahkan tanaman jahe secara total (Dinas Perkebunan Kabupaten Solok, 2005 komunikasi pribadi).

Sampai saat ini belum ada metode yang efektif, efisien, dan aman terhadap lingkungan untuk pengendalian penyakit layu bakteri Ralstonia solanacearum ras 4 pada tanaman jahe. Agar pertanaman jahe tidak musnah oleh serangan bakteri maka penelitian dan pengembangan teknik pengendalian layu bakteri yang efektif, efisien, praktis dan aman terhadap lingkungan sangat diperlukan.

Pengendalian penyakit tanaman yang disebabkan oleh penyakit bakteri sampai saat ini perlu mengacu pada konsep Pengendalian Hama Terpadu (PHT). Salah satu komponen dalam pengendalian tersebut adalah pengendalian hayati (Biological Control). Keuntungan penggunaan agens hayati dalam pengendalian penyakit tanaman antara lain: sumber daya lokal, dapat diperbanyak dengan teknologi sederhana dan mudah cara aplikasinya. Salah satu mikroorganisme yang dapat berperan sebagai agensia pengendali hayati yang potensial untuk dikembangkan adalah Fungi Mikoriza Arbuskular (FMA) Indigenus, karena FMA Indigenus yang dikembalikan pada tanaman asal akan lebih efektif dalam meningkatkan ketahanan tanaman terhadap penyakit.

Mekanisme yang diduga mendukung peran FMA dalam meningkatkan pertumbuhan dan pertahanan tanaman inang terhadap patogen akar adalah melalui pengurangan eksudat akar, peningkatan pertumbuhan tanaman inang, penimbunan unsur mikro dan produksi senyawa kimia yang bersifat antimikroba (Pfleger, 2000). Asosiasi simbiotik yang terjadi dibentuk antara tanaman, substrat dan FMA dapat meningkatkan kemampuan akar tanaman untuk mengeksplorasi tanah, mengakses air dan hara untuk tanaman, sehingga menguntungkan bagi tanaman karena meningkatnya kebugaran akibat naiknya serapan air (Marulanda et al., 2006), meningkatnya kelarutan dan angkutan fosfor (Bolan, 1991; Lange \& Vlek, 2000) dan resistensi terhadap penyakit (Vigo et al., 2000).

Berbagai tanaman yang dikolonisasi oleh FMA terjadi peningkatan ketahanan tanaman terhadap patogen dengan berkurangnya intensitas serangan oleh Phytophthora parasitica pada akar tanaman jeruk (Campbell, 1989). Tanaman tomat yang terkolonisasi FMA jenis Glomus sp dapat menekan perkembangan penyakit layu fusarium yang disebabkan oleh Fusarium oxysporum f.sp.lycopersici (Reflin, 1993), dan menurunkan intensitas serangan Xanthomonas axonopodis pv. vecatoria pada tanaman tomat
(Yusman, 2003). Hasil penelitian Yefriwati et al. (2005) pada tanaman pisang Cavendish yang diinokulasi dengan G. fasciculatum, G. etunicatum dan Acaulospora sp yang diberikan secara tunggal maupun gabungan (multispora) menunjukkan ketahanan bibit pisang terhadap R.solanacearum ras 2. Aplikasi $G$. fasciculatum dapat menginduksi ketahanan tanaman kedelai terhadap penyakit pustul bakteri yang disebabkan oleh Xanthomonas campestris pv. glycines (Harmet, 1999).

Informasi mengenai kemampuan FMA indigenus dalam pengendalian penyakit layu bakteri pada tanaman jahe masih terbatas dan belum ditemukan isolat FMA spesifik yang berpotensi dalam mengendalikan patogen pada tanaman jahe. Tujuan dari penelitian ini adalah untuk memperoleh isolat fungi mikoriza arbuskula (FMA) indigenus yang mampu mengendalikan penyakit layu bakteri pada tanaman jahe.

\section{METODE PENELITIAN}

Metode yang digunakan adalah Rancangan Acak Kelompok dengan 8 perlakuan dan 6 ulangan. Perlakuan adalah introduksi 8 isolat FMA indigenus yaitu Faa1, Faa2, Faa3, Faa4, Faa5, Faa6, Faa7, Faa8 dan kontrol. Bakteri Ralstonia solanacearum ras 4 diisolasi dari rimpang tanaman jahe terserang penyakit layu di lapangan. Data dianalisis dengan ANOVA dan dilanjutkan dengan uji DNMRT pada taraf nyata 5\%.

Pelaksanaan Penelitian. Penelitian ini dilaksanakan di Laboratorium Bakteriologi Jurusan Hama dan Penyakit Tumbuhan, Rumah Kaca, Fakultas Pertanian Universitas Andalas Padang dengan tahapan pelaksanaan penelitian adalah sebagai berikut:

Isolasi FMA Indigenus. FMA diisolasi dari tanah sekitar perakaran jahe sehat (rizosfir) pada lahan endemik penyakit layu bakteri $R$. solanacearum ras 4 di Nagari Aie Angek, Kabupaten Tanah Datar. Pengambilan sampel dilakukan menggunakan metoda Purpossive Random Sampling berdasarkan luas pertanaman jahe yaitu 0,5 ha. Isolat FMA diisolasi dengan metoda saring basah. Spora hasil isolasi dari tanah sampel diinokulasikan pada akar kecambah tanaman sorghum untuk mendapatkan spora tunggal sebagai kultur stater, selanjutnya diperbanyak secara massal pada akar tanaman jagung.

Perbanyakan isolat FMA. Isolat FMA indigenus hasil penyaringan, diinokulasikan pada akar kecambah sorghum sebagai kultur stater dipelihara pada tabung 
reaksi di Laboratorium. Setelah umur 1 bulan, tanaman bersama media pasir dipindahkan pada pot kemudian ditambahkan $200 \mathrm{~g}$ pasir steril dan dipelihara di rumah kaca, Setelah berumur dua bulan, bagian atas tanaman dipotong, selanjutnya sebanyak 200 g campuran akar sorghum dan media pasir sebagai sumber inokulan dimasukkan kedalam pot besar yang telah berisi $4 \mathrm{~kg}$ pasir steril, ditanami kecambah jagung, dipelihara dan dipupuk dengan larutan hara rendah P yaitu Gromor dengan konsentrasi $5 \mathrm{~g} / \mathrm{l}$ sebanyak $20 \mathrm{ml}$ per pot sampai kapasitas lapang. Setelah berumur 2 bulan bagian atas tanaman jagung dipotong dan akarnya bersama pasir digunakan sebagai sumber inokulum dan disimpan dalam ruangan berpendingin.

Isolasi bakteri Ralstonia solanacearum ras 4 penyebab penyakit. Ralstonia solanacearum ras 4, diisolasi dari rimpang tanaman jahe yang terserang penyakit layu bakteri di lapangan di Kanagarian Selayo Kabupaten Solok. Rimpang jahe didisinfeksi dengan larutan alkohol 70\%. Setelah itu dipotong dengan ukuran $1 \mathrm{~cm}$ dan digrinder dalam lumpang dan dimasukkan ke dalam phospat buffer salin (PBS) 0,02 M pH 7,2 dan divortex. Selanjutnya suspensi PBS tersebut digoreskan dalam media NA (Nutrien Agar) dan media TTC (tripenyl tetrazolium chlorida) dan diinkubasikan di dalam ruangan pada suhu kamar. Pengamatan dilakukan terhadap koloni bakteri yang tumbuh 48-72 jam setelah isolasi. Koloni bakteri yang diduga sebagai penyebab penyakit layu bakteri pada jahe kemudian diuji gram dengan menggunakan $\mathrm{KOH} \mathrm{3 \%}$ dan uji, kemudian dilanjutkan dengan uji patogenesitas pada tanaman jahe klon gajah yang berumur 2 bulan. Identifikasi bakteri mengacu pada Hayward (1991) dan Schaad et al. (2001).

\section{Penanaman benih dan Aplikasi isolat FMA.}

Benih yang digunakan adalah rimpang tanaman jahe putih besar yang rentan terhadap penyakit layu bakteri $R$. solanacearum ras 4 . Rimpang yang memiliki 2-3 mata tunas, seberat $50 \mathrm{~g}$, dicuci bersih dan direndam dalam alkohol $70 \%$ selama 15 menit, lalu dikeringkan. Selanjutnya ditanamkan pada dalam polybag yang telah berisi tanah steril bercampur pupuk kandang dengan perbandingan 3:1. Isolat FMA diberikan pada saat tanam sesuai perlakuan sebanyak 50 g per polybag .

Inokulasi bakteri Ralstonia solanacearum. Inokulasi dilakukan pada bibit jahe 2 bulan setelah tanaman. Inokulan diambil dari tanaman jahe yang menunjukkan gejala serangan penyakit layu di lapangan. Tanaman yang menunjukkan gejala serangan diambil, lalu batang dan rimpangnya dipotong, dilakukan pengenceran sampai $10^{-6}$. Suspensi yang terbentuk di ukur kekeruhannya dan dibandingkan dengan larutan $\mathrm{Mc}$ Farland ( $1 \mathrm{ml} \mathrm{BaCl}_{2} .9 \mathrm{ml} \mathrm{H}_{2} \mathrm{SO}_{4} 1 \%$ ) dengan kerapatannya diperkirakan $10^{6} \mathrm{UPK} / \mathrm{ml}$, lalu diinokulasikan sebanyak $20 \mathrm{ml}$ pada akar tanaman jahe yang telah dilukai dengan jarum pentul. Selanjutnya 1 $\mathrm{ml}$ suspensi dimasukkan kedalam 2 cawan petri dan masing-masing ditambahkan $15 \mathrm{ml}$ media NA dan trypenyl tetrazoliumchlorida (TTC) diinkubasi selama 24-48 jam, diamati koloni yang terbentuk, selanjutnya dimurnikan dengan memindahkan pada media agar miring. Uji konfirmasi untuk memastikan bahwa isolat yang diperoleh adalah $R$. solanacearum ras 4 dibuat mutan dengan menanam pada TTC yang mengandung antibiotik kanamycin.

Pengamatan. Peubah yang diamati pada setiap perlakuan adalah sebgai berikut:

1. Kejadian penyakit meliputi:

a. Periode inkubasi, diamati tiap hari setelah tanaman diinokulasi dengan $R$. solanacearum ras 4 sampai munculnya gejala serangan yang ditandai dengan menguningnya daun yang masih muda.

b. Persentase serangan layu yang diamati tiap hari, dihitung dengan mengunakan rumus Wang (1998):

$\mathrm{P}=\mathrm{a} / \mathrm{b} \times 100 \%$

Keterangan:

$\mathrm{P}=$ Persentase serangan layu

$\mathrm{a}=$ jumlah tanaman yang menunjukkan gejala layu/perlakuan

$\mathrm{b}=$ jumlah tanaman yang diamati/perlakuan

c. Lama kematian

2. Pertumbuhan tanaman

a. Jumlah anakan dan saat pertama munculnya anakan, diamati 2 minggu setelah tanam dengan interval waktu 1 minggu.

b. Tinggi tanaman, diamati mulai tanaman berumur 2 minggu setelah tanam dengan interval waktu 1 minggu, dengan mengukur tanaman dari pangkal sampai ujung batang.

c. Jumlah daun, dihitung mulai bibit tanaman berumur 1 minggu setelah tanam, sampai akhir pengamatan (4 bulan setelah tanam).

d. Berat rimpang, dihitung akhir pengamatan setelah tanaman berumur 8 bulan 


\section{Kolonisasi FMA pada akar tanaman jahe}

Pengamatan kolonisasi pada akar tanaman jahe dilakukan 3 minggu, 1 bulan dan 2 bulan setelah inokulasi. Akar diambil, dicuci dengan air mengalir, dikering anginkan, dipotong-potong sepanjang $1 \mathrm{~cm}$ dan dimasukkan kedalam tabung reaksi, ditambah $\mathrm{KOH} \mathrm{5 \%}$ sampai semua akar terendam dan dipanaskan diatas kompor selama 15 menit, dibilas dengan aquades, ditambahkan $\mathrm{KCl} 2 \%$ selama 10 menit dan dicuci dengan aqudes. Selanjutnya dilakukan staining (pewarnaan) menggunakan triphan blue selama 24 jam, kemudian larutan staining dibuang dan diganti dengan yang baru. Sepuluh potong akar yang telah direndam dalam pewarnaan di susun pada objek gelas, ditutup dengan cover gelas dan diamati dibawah mikroskop. Persentase koloni FMA dihitung berdasarkan bidang pandang (field of view) metode slide (Giovannetti dan Mosse, 1980). Bidang pandang yang menunjukkan kolonisasi diberi tanda (+) dan tanda (-) untuk yang tidak ditemukan tanda kolonisasi. Persentase kolonisasi oleh FMA dihitung sebagai berikut :

$$
\text { Persentase }=\frac{\text { Total }(+)}{\text { Total }(+) \operatorname{dan}(-)} \times 100 \%
$$

\section{Populasi bakteri $R$. solanacearum}

Populasi bakteri $R$. solanacearum pada tanaman jahe diisolasi dan dihitung pada hari ke 1, 3, 6 dan 9 setelah inokulasi. Bagian akar diambil sepanjang $2 \mathrm{~cm}$, dicuci dengan aquades steril, disterilisasi permukaan dengan alkohol $70 \%$ dan dibilas dengan aquades steril lalu dihancurkan. Selanjutnya dilakukan pengenceran secara seri sampai $10^{-6}$, diinokulasikan pada media tripenyl tetrazolium chlorida (TTC) dan diinkubasi pada suhu kamar pada temperatur $32^{\circ} \mathrm{C}$ selama 48 jam. Populasi bakteri dihitung dengan colony counter. Penghitungan koloni bakteri menggunakan rumus Klement et al. (1990):

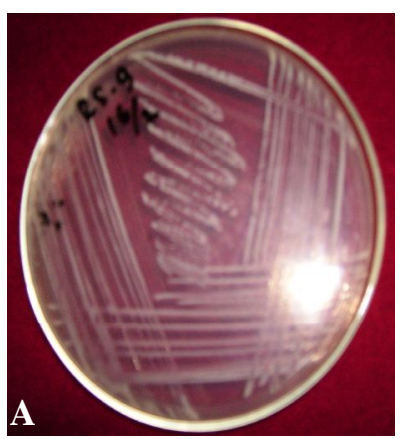

$$
\begin{aligned}
& \mathrm{JB}=\mathrm{A} \times \mathrm{B} \\
& \mathrm{JB}=\text { Jumlah bakteri } \\
& \mathrm{A}=\text { Jumlah koloni bakteri } \\
& \mathrm{B}=\text { Faktor Pengenceran }
\end{aligned}
$$

\section{HASIL DAN PEMBAHASAN}

Identifikasi tanaman yang terinfeksi penyakit layu bakteri di lapangan. Hasil pengamatan memperlihatkan bahwa tanaman jahe yang terinfeksi penyakit layu di lapangan menunjukkan gejala daun yang menguning dimulai dari titik tumbuh. Pada gejala lebih lanjut daun-daun yang lain menguning dan terlepas dari batang semu (pseudostem). Jika rimpang dipotong, terlihat bagian dalam yang lunak, berwarna coklat dan berbau busuk, adanya eksudat bakteri (ose bakteri) yang keluar dari batang semu dan rimpang. Gejala ini sesuai dengan gejala penyakit layu bakteri pada jahe yang dikemukakan oleh Hayward (1991); Supriadi (2000); Schaad et al. (2001).

Isolasi dan identifikasi bakteri $R$. solanacearum ras 4. Hasil isolasi terhadap bakteri dari rimpang tanaman jahe yang terserang penyakit layu, ditemukan koloni bakteri yang memiliki ciri-ciri berwarna putih susu pada media NA dan bewarna merah muda dengan media TTC, bentuk koloni mucoid, viscid (lengket), dengan pertumbuhan yang lambat (Gambar 1). Ciri-ciri tersebut sesuai dengan cirri-ciri koloni $R$. solanacearum ras 4 yang didiskripsikan oleh Hayward (1991) dan Schaad et al. (2001).

Hasil uji gram menunjukkan bahwa koloni bakteri yang ditemukan merupakan kelompok gram negatif. Hasil uji patogenesitas menunjukkan bahwa bakteri tersebut bersifat patogen dengan adanya klorosis dan layu pada tanaman jahe setelah disuntikkan suspensi bakteri . Gejala layu tanaman jahe, akibat serangan $R$. solanacearum ras 4 di lapangan dapat dilihat pada Gambar 2.

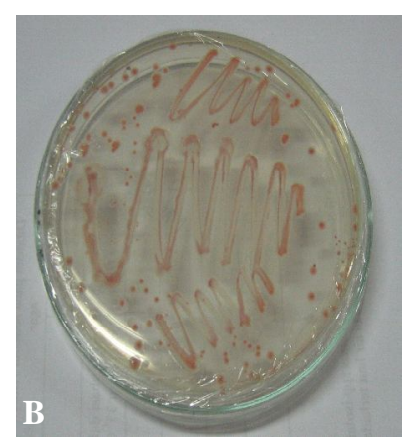

Gambar1. Koloni $R$. solanacearum ras 4 pada media NA (A) dan pada media TTC (B) setelah inkubasi selama 48 jam. 

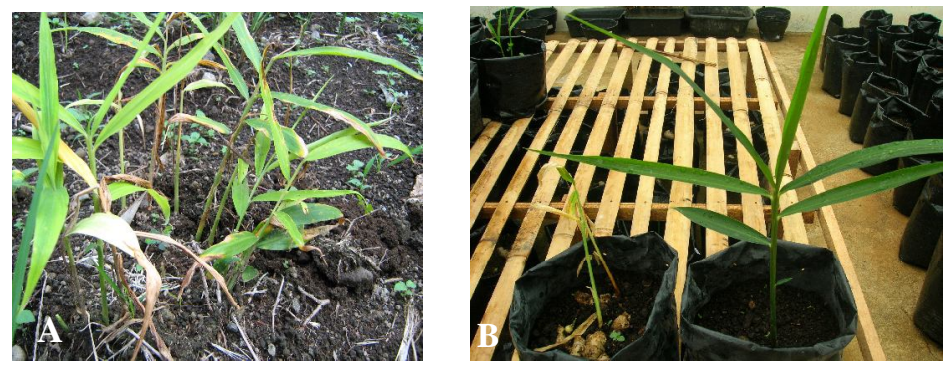

Gambar 2. Gejala serangan penyakit layu $R$. solanacearum ras 4, (A) tanaman jahe terserang penyakit di lapangan, (B) tanaman jahe diinokulasi $R$. solanacearum ras 4 di rumah kaca.

Isolasi FMA indigenus dan Tingkat Kolonisasi pada Akar Tanaman Jahe. FMA indigenus hasil isolasi dari rizosfir tanaman jahe yang diintroduksikan pada akar tanaman jahe adalah jenis glomus dengan spora berbentuk bulat, dinding tebal, bewarna orange kecoklatan dan jenis acaulospora dengan spora berbentuk bulat, berdinding tebal, warna coklat kehitaman. Semua akar jahe terkolonisasi oleh FMA dengan persentase kolonisasi yang bervariasi, kecuali tanaman kontrol, dengan terbentuknya arbuskula, hifa internal dan hifa eksternal (Gambar 3). Kolonisasi pada akar tanaman jahe telah terjadi pada 3 minggu setelah tanam yaitu $20-40 \%$. Persentase kolonisasi akar tanaman jahe oleh FMA meningkat sejalan dengan meningkatnya umur tanaman, kolonisasi tertinggi terjadi pada akar tanaman jahe 2 bulan setelah tanam yaitu 80-
90\%, dengan intensitas kolonisasi 4-5 (Tabel 1). Hal ini menunjukkan bahwa inokulum yang digunakan bersifat efektif dan kompatibel dengan tanaman jahe, sehingga mampu membentuk arbuskular, vesikula, hifa internal dan hifa eksternal, yang berperan dalam peningkatkan kebugaran tanaman dan ketahanan terhadap penyakit (Vigo et al., 2000) serta meningkatkan pertumbuhan tanaman jahe sebagai tanaman inang.

Ketahanan tanaman jahe terhadap serangan $R$. solanacearum ras 4 , disebabkan akar yang telah terkolonisasi FMA akan menghasilkan senyawa kimia yang bersifat sebagai antimikroba sehingga dapat melindungi perakaran tanaman dari patogen.

Menurut Brundrett (1999) struktur FMA dapat berfungsi sebagai pelindung biologi terhadap patogen akar karena (1) terdapatnya selaput hifa yang berfungsi
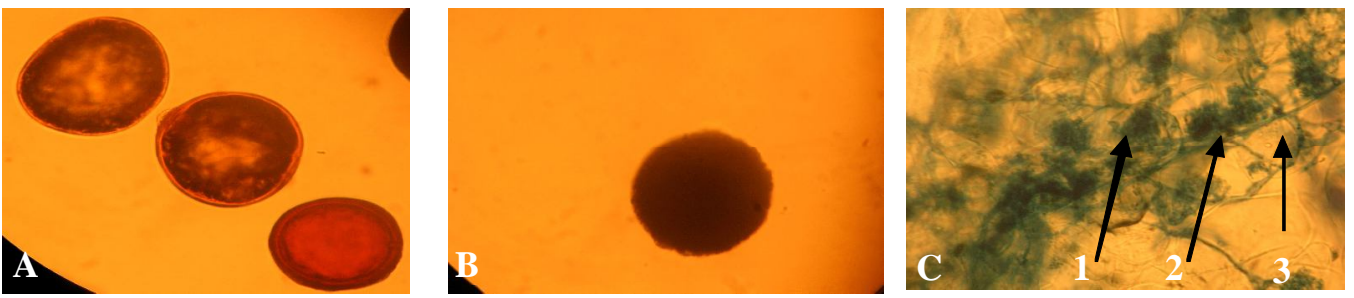

Gambar 3. Bentuk spora FMA dan kolonisasi pada akar tanaman jahe (a) jenis Glomus (b) jenis Acaulospora, (c) Kolonisasi akar tanaman jahe oleh FMA indigenus (1) Arbuskula, (2) hifa internal (3) hifa eksternal.

Tabel 1. Kolon isasi akar tanaman jahe setelah diintroduksi oleh FMA

\begin{tabular}{ccccc}
\hline No & Isolat & \% Kolonisasi FMA $(2 \mathrm{bst})$ & Inten sitas kolonisasi FMA & Kategori \\
\hline 1 & Faa-1 & 90 & 5 & Sangat tinggi \\
2 & Faa-2 & 80 & 4 & Sangat tinggi \\
3 & Faa-3 & 90 & 5 & Sangat tinggi \\
4 & Faa-4 & 90 & 5 & Sangat tinggi \\
5 & Faa-5 & 80 & 4 & Sangat tinggi \\
6 & Faa-6 & 80 & 4 & Sangat tinggi \\
7 & Faa-7 & 80 & 5 & Sangat tinggi \\
8 & Faa-8 & 80 & 4 & Sangat tinggi \\
9 & Kontrol & 0 & 0 & 0 \\
\hline
\end{tabular}


sebagai penghalang masuknya patogen, (2) mikoriza menggunakan hampir semua kelebihan karbohidrat dan eksudat lainnya sehingga tercipta lingkungan tidak sesuai bagi perkembangan patogen, (3) FMA dapat mengeluarkan senyawa kimia yang dapat mematikan atau menghambat pertumbuhan patogen, dan (4) akar tanaman yang sudah terkolonisasi FMA tidak dapat atau sulit dipenetrasi oleh patogen karena patogen harus berkompetisi dengan FMA terlebih dahulu. Introduksi FMA dapat mempengaruhi respon fisiologis dan biokimia, melalui peningkatan aktivitas enzim dan kandungan kimia tanaman yang menghambat perkembangan patogen (Ming \& Hui, 1996).

Kejadian Penyakit. Pengamatan terhadap kejadian penyakit pada bibit jahe yang diintroduksi dengan FMA menunjukkan bahwa 4 isolat yaitu Faa1, Faa2, Faa4 dan Faa5 memiliki kemampuan dalam mengendalikan penyakit layu bakteri pada tanaman jahe dan tidak ada tanaman yang mati sampai akhir pengamatan (120 hari setelah inokulasi) dengan efektivitas $100 \%$. Tanaman jahe yang diintroduksi dengan FMA isolat Faa1, Faa2, Faa4, dan Faa15, tidak memperlihatkan gejala layu sampai akhir pengamatan, sedangkan bibit jahe yang diintroduksi dengan FMA isolat Faa3, Faa6, Faa7, dan Faa8 tidak mampu mencegah timbulnya gejala layu dengan masa inkubasi 7-14,33 hari, tanaman terserang penyakit layu $16,66-33,33 \%$, lama kematian $31,67-45,33$ hari, namun masa inkubasi paling cepat terdapat pada kontrol yaitu 4,16 hari setelah inokulasi, tanaman layu mencapai $100 \%$ dan lama kematian 14,67 hsi (Tabel 2.)

Untuk melihat kemampuan isolat FMA dalam mengendalikan penyakit layu bakteri dilakukan pelacakan populasi $R$. solanacearum ras 4 yang terdapat pada akar tanaman jahe (Gambar 4).
Pengamatan terhadap populasi $R$. solanacearum ras 4 pada akar tanaman jahe, dapat diketahui bahwa seluruh tanaman jahe terinfeksi oleh patogen tersebut, akan tetapi tidak semua tanaman memperlihatkan gejala layu. Terdapat variasi kerapatan populasi bakteri $R$. solanacearum ras 4 pada tanaman jahe yang diintroduksi FMA. Populasi $R$. solanacearum ras 4 pada tanaman yang diintroduksi isolat Faa 1, Faa2, Faa4 dan Faa5, masih tinggi pada 3 hari setelah inokulasi (hsi), akan tetapi pada 6 dan 9 hsi terjadi penurunan populasi, dan populasi bakteri tertinggi terdapat pada tanaman kontrol.

\section{Pertumbuhan Tanaman Jahe yang diintroduksi} FMA dan diinokulasi $R$. solanacearum ras 4 . Introduksi FMA indigenus pada tanaman jahe juga berpengaruh terhadap perumbuhan tanaman. Pengamatan pertumbuhan tanaman jahe yang diintroduksi dengan FMA meliputi pembentukkan anakan, tinggi tanaman dan jumlah daun menunjukkan bahwa isolat FMA yang berbeda menyebabkan pengaruh yang berbeda pula terhadap pertumbuhan tanaman (Tabel 3).

Hasil Analis sidik ragam terhadap pertumbuhan tanaman jahe menunjukkan perbedaan yang nyata antara tanaman yang diintroduksi iolat FMA indigenus dibanding kontrol $(\mathrm{P}<0,01)$. Tanaman jahe yang diintroduksi dengan isolat Faa4 menghasilkan pertumbuhan tertingi yaitu jumlah anakan 5 buah (peningkatan 150\%), tinggi tanaman 77,8 cm $(98,6 \%)$ dan jumlah daun 15,5 lembar $(115,7 \%)$ sedangkan tanaman kontrol menghasilkan 2 anakan, tinggi tanaman $38,8 \mathrm{~cm}$ dan jumlah daun 7,2 helai.

Aplikasi FMA juga berpengaruh terhadap produksi rimpang tanaman jahe. Tanaman jahe yang diintroduksi Isolat FMA indigenus yang tidak terserang patogen $R$.

Tabel 2. Kejadian penyakit layu pada tanaman jahe yang diintroduksi FMA dan diinokulasi $R$. Solanacearum ras 4

\begin{tabular}{lccc}
\hline \multirow{2}{*}{ Isolat FMA } & \multicolumn{3}{c}{ Kejadian penyakit } \\
\cline { 2 - 4 } & Masa inkubasi (hari) & Tanaman layu $(\%)$ & Lama kematian (hari \\
\hline Faa 1 & $120^{*}$ & $*$ & $120^{*}$ \\
Faa2 & $120^{*}$ & $*$ & $120^{*}$ \\
Faa4 & $120^{*}$ & $*$ & $120^{*}$ \\
Faa5 & $120^{*}$ & $*$ & $120^{*}$ \\
Faa3 & 14,33 & 16,66 & 31,67 \\
Faa6 & 9,83 & 16,66 & 45,33 \\
Faa7 & 7 & 33,33 & 45,33 \\
Faa8 & 9 & 16,66 & 39,33 \\
Kontrol & 4,16 & 100 & 14,67 \\
\hline
\end{tabular}

Keterangan $*$ = tidak ada tanaman terserang penyakit layu 


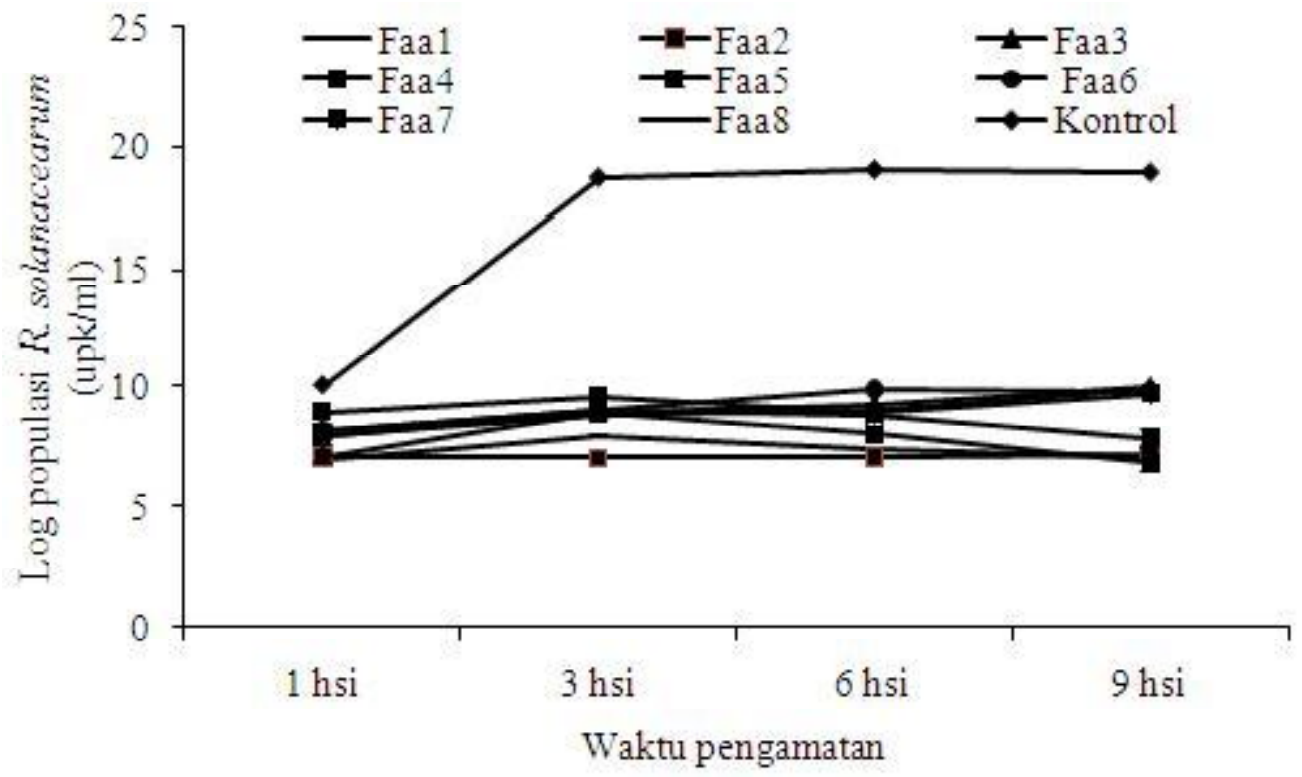

Gambar 4. Logaritma populasi $R$. solanacearum ras 4 pada akar tanaman jahe yang diintroduksi dengan FMA.

Tabel 3. Pertumbuhan tanaman jahe setelah diinokulasi dengan FMA Indigenus 14 minggu setelah inokulasi

\begin{tabular}{cccccccc}
\hline No & $\begin{array}{c}\text { Isolat } \\
\text { FMA }\end{array}$ & $\begin{array}{c}\text { Jumlah } \\
\text { anakan } \\
\text { (buah) }\end{array}$ & $\begin{array}{c}\text { Peningkatan } \\
(\%)\end{array}$ & $\begin{array}{c}\text { Tinggi } \\
\text { Tanaman }(\mathrm{cm})\end{array}$ & $\begin{array}{c}\text { Peningkatan } \\
(\%)\end{array}$ & $\begin{array}{c}\text { Jumlah } \\
\text { daun } \\
(\text { helai })\end{array}$ & $\begin{array}{c}\text { Peningkatan } \\
(\%)\end{array}$ \\
\hline 1 & Faa1 & $3^{\mathrm{ab}}$ & 50 & $63.4^{\mathrm{c}}$ & 75.5 & $12.0^{\mathrm{c}}$ & 73.4 \\
2 & Faa2 & $5^{\mathrm{b}}$ & 150 & $52.7^{\mathrm{b}}$ & 37.6 & $10.3^{\mathrm{b}}$ & 44.5 \\
3 & Faa3 & $4^{\mathrm{ab}}$ & 100 & $63.4^{\mathrm{c}}$ & 65.3 & $12.5^{\mathrm{c}}$ & 73.6 \\
4 & Faa4 & $5^{\mathrm{b}}$ & 150 & $77.8^{\mathrm{d}}$ & 98.6 & $15.5^{\mathrm{d}}$ & 115.7 \\
5 & Faa5 & $4^{\mathrm{ab}}$ & 100 & $53.3^{\mathrm{b}}$ & 39.1 & $10.2^{\mathrm{b}}$ & 43.0 \\
6 & Faa6 & $5^{\mathrm{b}}$ & 150 & $54.9^{\mathrm{b}}$ & 43.2 & $12.0^{\mathrm{c}}$ & 66.7 \\
7 & Faa7 & $3^{\mathrm{ab}}$ & 50 & $76.3^{\mathrm{d}}$ & 98.4 & $15.3^{\mathrm{d}}$ & 112.9 \\
8 & Faa8 & $4^{\mathrm{ab}}$ & 100 & $64.0^{\mathrm{c}}$ & 66.9 & $9.8^{\mathrm{ab}}$ & 36.2 \\
9 & Kontrol & $2^{\mathrm{a}}$ & 0 & $38.8^{\mathrm{a}}$ & 0.0 & $7.2^{\mathrm{a}}$ & 0.0 \\
\hline
\end{tabular}

Keterangan: Angka-angka pada kolom yang sama yang diikuti oleh huruf kecil yang sama tidak berbeda nyata menurut uji lanjut DNMRT pada taraf nyata $5 \%$.

solanacearum ras 4 menghasilkan rimpang lebih banyak yaitu $202 \mathrm{~g}$ (peningkatan 400\%) dan bagian atas tanaman 68 (peningkatan 598,3\%), dibanding kontrol (Gambar $5)$.

Hasil penelitian ini menunjukkan isolat FMA indigenus rizosfir tanaman jahe yang diintroduksi pada bibit jahe mampu menahan perkembangan penyakit layu bakteri yang disebabkan $R$. solanacearum ras 4 dengan kemampuan yang bervariasi. FMA indigenus juga mampu meningkatkan pertumbuhan dan produksi tanaman jahe, yang menunjukkan bahwa, isolat FMA ini sudah beradaptasi dengan lingkungan tersebut sehingga menghalangi patogen masuk ke dalam jaringan tanaman. Mekanisme FMA dalam mengenalikan patogen tanaman dapat terjadi melalui dua cara yaitu secara langsung melalui kompetisi dan antibiosisi dan secara tidak langsung melalui induksi ketahanan sehinga terhalangnya serangan patogen pada akar bermikoriza (Kobayashi \& Branch, 1991). Mekanisme pengendalian secara tidak langsung adalah melalui respon fisiologis dan biokimia dengan terjadinya peningkatan aktivitas enzim dan peningkatan kandungan senyawa kimia yang bersifat sebagai antimikroba yang dihasilkan tanaman (Ming \& Hui, 1996).

Hasil pengujian terhadap 8 isolat FMA indigenus dari rizosfir tanaman jahe telah teresleksi 4 isolat yang mampu meningkatkan ketahanan tanaman jahe terhadap $R$. solanacearum ras 4 mencapai $100 \%$, sedangkan 


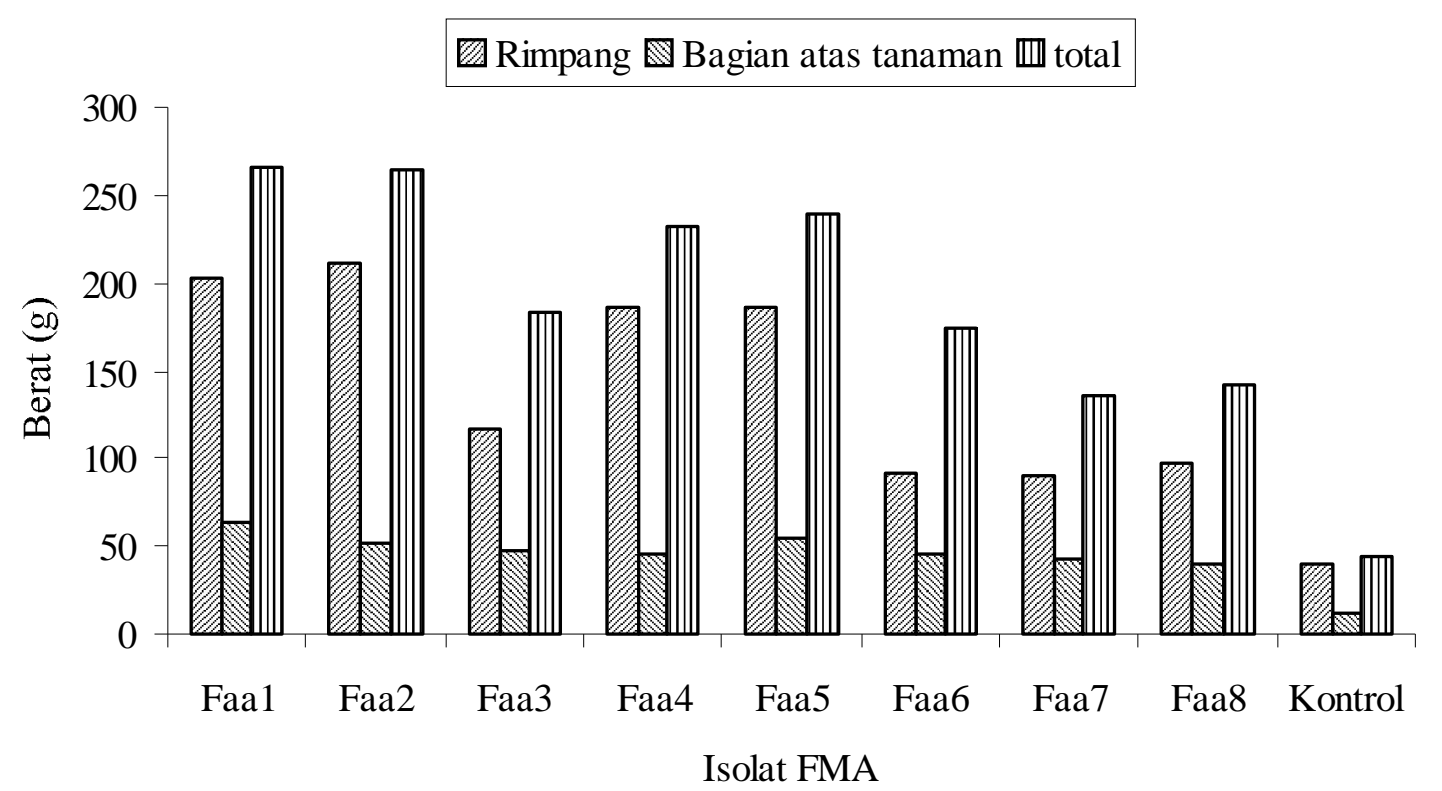

Gambar 5. Hasil Tanaman jahe yang diintroduksi isolat FMA indigenus

tanaman kontrol mengering dan akhirnya mati sampai akhir pengamatan (14 msi). Gejala serangan dapat diamati pada bagian luar tanaman jahe yaitu mulai menguningnya daun yang masih muda yang diikuti dengan daun yang sudah tua dan diikuti lepasnya tangkai daun dari batang semu.

Dari penelitian ini menunjukan bahwa pengujian kemampuan mikroorganisme antagonis dalam mengendalikan patogen tanaman lebih baik secara in planta, karena kompleksnya mekanisme agens hayati dalam mengendalikan patogen tanaman, ada yang bersifat langsung terhadap patogen seperti kompetisi, hiperparasit, antibiosis, lisis, ada juga yang bersifat tidak langsung, seperti melalui peningkatan ketahanan/ kebugaran tanaman sehingga dapat menghambat perkembangan patogen (induksi ketahanan) dan peningkatan pertumbuhan tanaman serta aman terhadap lingkungan.

\section{SIMPULAN}

1. Hasil isolasi dari tanah rizosfir tanaman jahe di nagari Aie Angek Kabupaten Tanah Datar, diperoleh 8 isolat FMA Indigenus jenis Glomus spp dan Acaulospora spp yang memiliki tingkat kolonisasi yang tinggi pada tanaman jagung sebagai tanaman indikator yaitu 80$90 \%$,

2. Isolat FMA mampu menekan perkembangan penyakit layu bakteri Ralstonia solanacearum ras 4 pada tanaman jahe. Sebanyak 4 isolat FMA mampu meningkatkan ketahana tanaman jahe terhadap penyakit layu mencapai $100 \%$, dan 4 isolat lainnya memiliki kemampuan yang bervariasi dalam menekan penyakit layu bakteri yaitu $66,5-83,3 \%$, dan

3. Inokulasi FMA Indigenus mampu meningkatkan pertumbuhan dan produksi jahe, dengan peningkatan jumlah anakan $150 \%$, tinggi tanaman $98,6 \%$, jumlah daun $115,7 \%$, hasil rimpang $400 \%$ dan bagian atas tanaman 598,3\%.

\section{SANWACANA}

Kami mengucapkan terima kasih kepada Direktorat Penelitian Pengabdian Kepada Masyarakat (DP2M) Direktur Jendral Pendidikan Tinggi Departemen Pendidikan Nasional atas bantuan biaya yang telah diberikan untuk melaksanakan penelitian ini melalui program penelitian Hibah Bersaing XV tahun 2008/2009.

\section{DAFTAR PUSTAKA}

Annonim 1989. Budidaya Jahe dan Pemasarannya. Departemen Pertanian Indonesia.

Alvarez MA, Trotter KJ, Swafford MD \& Brestecky JM. 2004. Characterization and Detection of Ralstonia solanacearum strains Causing Bacterial Wilt of Ginder in Hawaii. Hal 471-477. In: Allen C, Prior P \& Hayward AC. Bacterial Wilt Disease and The R. solanacearum Species Complex. APS Press, St Paul, Minnesota. 
Badan Pusat Statistik 2003. Luas Tanam dan Produksi Perkebunan Rakyat Menurut Jenis Tanaman. Jakarta.

Bolan NS. 1991. A critical review on the role of mycorrhyzal fungi in the Uptake of phosphorus by plant. Plant and Soil 134:189-207.

Brundrett M, Bougher N, Dell B, Grove T \& Malajczuk N. 1996. Working with Micorrhyzas in Forestry and Agriculture. ACIAR. Canberra.

Campbell R. 1989. Biological Control of Microbial Plants Pathogens. Cambridge University Press. Cambridge.

Elphinstone JG. 2004. The Current Wilt Situation A Global Overview. Hal 9-28. In Allen C, Prior P \& Hayward AC. Bacterial Wilt Disease and The R. solanacearum Species Complex. APS Press, St Paul, Minnesota.

Giovannetti M \& Mosse B. 1980. An Evaluation technique for measuring vesicular arbuscular mycorrhyzal infection in root. New Phytopathol. 84:489-500.

Hadad MDA. 1989. Ketahanan Beberapa Klon Jahe Terhadap Penyakit Busuk Rimpang $P$. solanacearum. Buletin Penelitian Tanaman Rempah dan Obat. Vol. IV. No.1.

Harmet. 1999. Peranan Glomus fasciculatum dan Pupuk Fosfor dalam Meningkatkan Ketahanan Tanaman Kedelai terhadap Penyakit Pustul Bakteri (Xanthomonas sp) [Tesis]. Sekolah Pascasarjana Universitas Andalas.

Hayward AC. 1991. Biology and Epidemiology of Bacterial wilt Caused by P. solanacearum Ann. Rev. Phytopathol. 29:65-87.

Klement Z, Rudolph K \& Sands DC. 1990. Inoculation of Plant Tissues. Methods in Phytobacteriology. Budapest: Akademiae Kiado.

Kobayashi N \& Branch K. 1991. Biological Control of Soil Born Desease WithVesicular Arbuscular Mycorrhyza Fungi and Charcoal Compost. In Proceeding of International seminar
Biological control of Plant Disease And Virus vector. Tsukuba. Japan.

Ming T \& Hui C. 1996. The effect of Vesicular Arbuscular Mycorrhyzas on Resistance of Poplar to a cancer Fungus (Dothiorella gregaria). In Brundett et al, 1994. Mycorrhyzas for Plantation Forestry in Asia. Proceeding of an International Symposium and Workshop Kaiping, Guangdong. China.

Pfleger LF \& Linderman RG. 2000. Mycorrhizae and Plant Health. APS Press, St Paul, Minnesota.

Reflin. 1993. Pengaruh Inokulasi Jamur MVA dan Fusarium f.sp.lycopersici terhadap Infeksi Jamur Fusarium dan Pertumbuhan Tanaman Tomat. Program Pacasarjana Universitas Gadjah Mada. Yogyakarta.

Stansbury C, Mc Kirdy S \& Power G. 2001. Moko Disease Ralstonia solanacearum (race 2). Factsheet. No.21/2001.

Supriadi. 2000. Penyakit Layu Bakteri ( $R$. solanacearum) Pada Tumbuhan Obat dan Strategi Penanggulangannya. Balai Penelitian Tanaman Rempah dan Obat Bogor.

Schaad NW, Jones JB \& Chun W. 2001. Laboratory Guide for Identification of Plant Pathogenic Bacteria. APS Press, St Paul, Minnesota.

Suratman, Djauhari, E., Rachmat, Sudiarto, 1987. Pedoman Bercocok Tanam Jahe (Zingiber officinale Rosc). Balai Penelitian Tanaman Rempah Dan Obat. Bogor.

Trubus. 1990. Jahe Gajah Lebih Untung Kalau Dipanen Muda. Peluang Bisnis. Majalah Pertanian Edisi Maret 1990. No. 244 Th XXI. 4 - 5.

Tumbuh. 1991. Ekspor Jahe Masih Terbuka Lebar. Peluang Investasi. Majalah Pertanian No. 20. Tahun II. 10-13.

Vigo C, Norman JR \& Hooker JE. 2000. Biokontrol of the Phatogen Phytopthora parasitica by arbuscular mycorrhizal fungi in roots. Physiologia Plantarum 125:393-404. 
Von Alten, Linderman H \& Schonbeck AF. 1993. Stimulation of Vesicular Arbuscular Mycorrhiza by Fubgicides or bacteria. Mycorrhiza 2: 167173.

Wang JF. 1998. Basic Protocol for Conducting Research on Tomato Bacterial Wilt Cause by Ralstonia solanacearum. shanhua; Asia Vegetable Research and Development center.

Wattimena GA. 2004. Biotechnology for Sustainable agriculture Development. Makalah pada Pelatihan Peningkatan SDM Perguruan Tinggi Dalam Pengembangan Sistim Pertanian Berkelanjutan. Universitas Andalas Padang.
Yefriwati, Habzar T, Reflin I \& Muas. 2005. Aplikasi Beberapa Jenis Cendawan Mikoriza Arbuskula (CMA) Dalam Meningkatkan Ketahanan Bibit Pisang Terhadap Serangan Penyakit Layu Bakteri Ralstonia solanacearum ras 2. Seminar dan Workshop Asosiasi Mikoriza Indonesia. Jambi Indonesia.

Yusman. 2003. Uji Kemampuan Beberapa Jenis Cendawan Mikoriza Arbuskula Dalam menginduksi Ketahanan Tomat Terhadap Penyakit Bercak Bakteri (Xanthomonas axonopodis pv. Vecatoria) [Tesis]. Sekolah Pascasarjana Universitas Andalas. 